\title{
Michael McATEER, ed., Silence in Modern Irish \\ Literature, Leiden, Brill, 2017
}

\section{Bridget English}

\section{(2) OpenEdition}

\section{Journals}

\section{Electronic version}

URL: http://journals.openedition.org/etudesirlandaises/5390

DOI: 10.4000/etudesirlandaises.5390

ISSN: 2259-8863

\section{Publisher}

Presses universitaires de Caen

\section{Printed version}

Date of publication: 29 November 2017

Number of pages: 154-156

ISBN: 978-2-7535-7388-8

ISSN: 0183-973X

\section{Electronic reference}

Bridget English, « Michael McAteER, ed., Silence in Modern Irish Literature, Leiden, Brill, 2017 », Études irlandaises [Online], 42-2 | 2017, Online since 29 November 2017, connection on 23 September 2020. URL : http://journals.openedition.org/etudesirlandaises/5390; DOI : https://doi.org/10.4000/ etudesirlandaises.5390

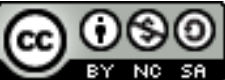

Études irlandaises est mise à disposition selon les termes de la Licence Creative Commons Attribution - Pas d'Utilisation Commerciale - Partage dans les Mêmes Conditions 4.0 International. 
at three distinct periods in Beckett's life, into his visual aesthetic as implemented in his works for theatre, television and film.

The central thesis of the book is that the three painters which Beckett knew most intimately form "a constellation of minor painting" which "challenges the dominant givens of a canonical tradition" (12) and relentlessly looks for alternatives to the relations of domination and possession inherent in the regime of representation. Thus, Lloyd argues, Beckett's engagement with the works of Jack B. Yeats, Bram van Velde and Avigdor Arikha pointed him out of the impasse of "the subject-object relation", towards a visual aesthetic that desists from the ethical and political tenets of the Western tradition of representation. The eponymous "thing" which Beckett relentlessly sought to express (not capture!) is what remains of the human after the cataclysms which have left "humanity in ruins" in the post-war era: neither subject nor object, but a "human thing" suspended among its things that resists total annihilation. As he does elsewhere in his oeuvre, Lloyd weaves together the aesthetic, ethical and political strands of artistic work, lucidly teasing out the various implications of the process of representation - and convincingly showing the congruence between the aesthetic and political senses of the term. In the process, he offers a decisive contribution to recent reappraisals of Beckett as a profoundly political writer.

While the book offers a tantalizingly new way of thinking about Beckett's visual imagination and of understanding his work with theatre, television and film, it also provides a fascinating account of the debates raised by formal experimentations in Western post-war painting. More importantly, perhaps, it also provides superb reproductions of over sixty works by Yeats, Van Velde, Arikha and many others, and invents a kind of ethical ekphrasis which seeks to give an account of the paintings (with special emphasis on their materiality, on the quality and degree of exposure of the canvass, or the thickness of the impasto) without "reading" them, and thus reducing them to objects of the commentator's subjective, interpretive gaze. Finally, in tracing Beckett's dogged pursuit of an art form that would not somehow imply a form of domination, David Lloyd's new book makes a compelling argument for the value of human thingness.

Alexandra Poulain

Michael McAteer, ed., Silence in Modern Irish Literature, Leiden, Brill, 2017, vII-217 p., ISBN 978-90-04-34273-6, €116,00.

Staining the Silence... Celebrating the virtues of silence over literary expression, Samuel Beckett famously remarked, "Every work is like an unnecessary stain 
on silence and nothingness", pointing to the failure of literature to adequately capture the horrors of a post-war world. Despite this statement, Beckett did not let the corrupting influence of such stains on silence hinder his own artistic production, which explores these themes at length. The complex relationship between writing and silence is the subject of an impressive new collection of essays, Silence in Modern Irish Literature, edited by Michael McAteer, which ambitiously tackles this vast topic in an Irish context, examining the multiple meanings of silence and the difficulties of examining a subject matter that is by its very nature challenging to categorize or represent.

In his introduction to the collection McAteer analyses silence in Austin Clarke's "The Planter's Daughter", pointing to some of the inherent problems in investigating this theme. Beginning with Clarke's lines "Men that had seen her/ Drank deep and were silent", McAteer writes: "The silence to which Clarke's lines refer carries a range of meanings that direct readers towards the complexity and importance of silence in modern Irish literature" which include "psychological, ethical, topographical and spiritual aspects" (1). The book is accordingly divided into four sections that correspond with one of these categories of silence: Psychologies of Silence, Ethics of Silence, Places of Silence, and Spirits of Silence. This organizational technique works well for the most part, putting thematically similar essays into dialogue.

One of the challenges of addressing a topic as broad as silence, as McAteer's introduction aptly demonstrates, is that the meaning of silence varies according to the literary form and context in which it occurs. Silence in Modern Irish Literature does an admirable job of tackling this challenge, featuring essays that cover poetry, drama, and prose as well as other more underdeveloped genres such as visual "mural language" and the confessional. As this collection makes clear, there is no one way of interpreting silence, but there is nevertheless great value attached to the study of this pervasive theme, as it can uncover the marginalized voices that so often go unheard.

Silence in Modern Irish Literature is notable not only for its inclusion of a diversity of genres but also for the range of historical periods and the variety of methodological approaches it incorporates. Unfortunately, it is not possible to comment on all fifteen of the fascinating essays in the collection here, but some of the most memorable entries include Emilie Morin's intriguing links between psychiatric experimentation and mystical Symbolism in early twentieth-century Paris and the influence that these statements on silence had on Beckett and the "modernist aesthetic of muteness" (45) and Heather Ingam's discussion of the silencing of the Anglo-Irish in Elizabeth Bowen's novels, arguing that Bowen urges women to move out of the silence and claim language for themselves. An excellent essay by Willa Murphy on the Irish Catholic confessional connects the 
fixation on the confessional after the 1801 Act of Union, with current debates surrounding clerical child abuse. In one of the strongest essays in the collection, Anne Fogarty draws parallels between the censorship of Kate O'Brien's The Land of Spices and that text's concern with sexual repression, the feminine, and the unspoken, arguing that silence is an integral aspect of the symbolic structures of The Land of Spices and reveals the ways that the condition of modern Ireland affected female development. In a fascinating exploration of the language of signs and images Stephanie Schwerter discusses the challenges of translating Belfast's urban murals into different cultural environments and what is silenced by translation. Thierry Robin's penultimate essay suggests that Dermot Healy's A Fool's Errand interweaves silence and speech in order to merge past and future, living and dead. Finally, the Collection ends on a haunting note with Virginie Roche-Tiengo's demonstration of the ways that the dead impact on the silences of the living in Brian Friel's drama.

In its vast scope of essays, from the psychic to the topographic, which touch on questions of gender, place, belonging, testimony, language, and death, Silence in Modern Irish Literature leaves a necessary stain on the silence that has too long suppressed voices that are only now beginning to be heard. In its focus on gaps and ruptures in speech, Silence in Modern Irish Literature marks a unique and important contribution to Irish Studies, one that alters approaches to reading practices themselves by shifting the focus from what is articulated, to what remains unspoken, but which nevertheless conveys meaning.

Bridget ENGLISH

Alexandra Poulain, Irish Drama, Modernity and the Passion Play, London, Palgrave Macmillan, 2016, 264 p., ISBN 978-1-349-94962-5, \$99.99 (hardcover), ISBN 978-1-349-94963-2, \$79.99 (ebook).

Irish Drama, Modernity and the Passion Play is a welcome, refreshing contribution to critical studies of twentieth-century Irish drama. It takes its readers on a journey to varied, often unexplored corners as it engages with a wide and eclectic range of plays. Its detailed and contextualised close readings highlight the richness and complexity of the field of twentieth-century Irish theatre. The book looks anew at canonical plays, such as, for example, J. M. Synge's The Playboy of the Western World (1907), W. B. Yeats's Calvary (1920), Samuel Beckett's Endgame (1957), Brian Friel's Faith Healer (1979) or Tom Murphy's Bailegangaire (1985). Crucially, it also offers perceptive analyses of lesser known plays 